DE

DE GRUYTER

OPEN
Journal of Intercultural Management

Vol. 7, No. 3, September 2015, pp. 119-132

DOI 10.1515/joim-2015-0024

Magdalena Grębosz ${ }^{24}$

Lodz University of Technology

Jean-Marc Pointet

Université Paris-Est, ESIEE-Paris and Institut de Recherche en Gestion, France

\title{
The "Retro" Trend in Marketing Communication Strategy of Global Brands
}

\begin{abstract}
The main objective of this article is to present the relevance and possibilities of using the "retro" trend in marketing communication strategy of global brands, taking into account intercultural environment of companies. In the article the examples of retro-communication of global brands are presented. The results of comparative studies of attitudes of French and Polish consumers concerning retro communication campaigns of global brands are also analysed, taking into account the product category, as well as geographic and cultural consumers characteristics. The results of the research confirm the significance of retro marketing communication in case of global brands in current market conditions and their impact on consumers attitudes.
\end{abstract}

Key words: retromarketing, globalisation, marketing communication strategy, consumers attitudes, brand, brand management.

\section{Introduction}

In period of anxiety connected with economic recessions, political crisis, national conflicts, but also personal insecurity and social pressure, consumers search for the brands that deliver additional value connected with feeling of security and calm. In a postmodern society, the consumer is less interested in maximising profit than enjoying hedonist gratification (like fun shopping in fantasy atmospheres). In this way, with its "re-enchanted offering" [Firat and Venkatesh

\footnotetext{
${ }^{24}$ magdalena.grebosz@p.lodz.pl
} 
1995, p. 239], "the market acts as a release for emotions produced by projections in gratifying universes" [Badot 2014, p. 226]. The higher the level of insecurity that consumers experience in their current life, the more likely they revert to the past [Baker and Kennedy 1994, pp. 169-171]. Thus, consumers' insecurity, which is a generalized sense of uncertainty, vulnerability and fear, may result in positive attitudes of consumers towards brands using retro marketing communication that appeals to the past [Zhou et al., 2013, pp. 2406-2407]. Retro trend in marketing communication can help create a tangible connexion to the past by providing the positive nostalgic feelings.

The main objective of this article is to present the relevance and possibilities of using the "retro" trend in marketing communication strategy of global brands, taking into account intercultural environment of companies. In the article the examples of retro-communication of global brands are presented. The results of comparative studies of attitudes of French and Polish consumers concerning retro communication campaigns of global brands are also analysed, taking into account the product category, as well as geographic and cultural consumers characteristics.

Research concerning evaluation of global brands promoted in retro-style was conducted among young (18-24 years old) French and Polish consumers. The authors conducted a study on a group of 200 consumers in France in March 2015 and on a group of 200 consumers in Poland in April 2015, using the indirect method of gathering information by survey technique.

\section{Current state of knowledge}

According to Brown [2001, pp. 303-307] "marketing is in the throes of a retromarketing revolution". The turn of the 21st century has turned out to be a time of "retro shock", of revivals, replicas, remakes, recreations, reproductions and consequently of looking back to see ahead.

The concept of retromarketing is based on nostalgic attitudes of consumers. The nostalgia as a theoretical construct in the consumer psychological context was prompted by Davis [1979]. According to Davis [1979, p. 18] nostalgia is a "positively toned evocation of a lived past in the context of some negative feeling toward the present or impending circumstance". He makes reference to the source of the positive emotion evoked by the past and explained that "the nostalgic feeling is infused with imputations of past beauty, pleasure, joy, satisfaction, goodness, happiness, love, and the like, in sum, any or several of the positive affects of being". Davis [1979, pp. 18-24] postulated also that nostalgia usually occurs in the context of fear, discontent, anxiety, and uncertainty, and it aims at alleviating negative feelings. Several definitions and descriptions of nostalgia have emerged also in the retromarketing literature over the last years. Belk [1990, pp. 669-672] and Divard and Robert-Demontrond [1997, pp. 41-43] include some reference to actual stimuli 
(objects, scenes, smells etc.) that may prompt a nostalgic response. Holbrook and Schindler [1991, pp. 330-333], described nostalgia as a time-based preference, more specifically, as "a preference (general liking, positive attitude, or favourable affect) toward objects (people, places, or things) that were common (popular, fashionable, or widely circulated) when one was younger (in early adulthood, in adolescence, in childhood, or even before birth)". According to Kessous et al. [2015, p. 188], this definition has become the reference. Thus, to integrate into existing products historical codes and symbols is not evidence of regret. On the contrary, according to Maffesoli [2003, p. 125], they reinforce personal identity of a consumer anchored in its roots. It is a stable point, an emotional pillar, a founder or comforting regression to make a new start in anxiety-provoking environment. Despite some differences, most conceptualizations of nostalgia view it as an affective state, mood, or emotion that is somehow triggered by one's thoughts of the past.

The interest of academic and research communities focuses primarily on the analysis of the use of elements of nostalgia in advertising [Stern 1992; Pascal, Sprott and Muehling 2002; Perrusson 2003; Muehling and Sprott 2004; Reisenwitz, Iyer and Cutler 2004; Marchegiani \& Phau 2010; Muehling and Pascal 2011; Muehling 2013; Muehling, Sprott, Sultan 2014]. The results of research conducted by foreign researchers confirm the positive impact of nostalgia on the attitudes and behaviours of consumers in the area of advertising.

Planning of brand marketing communication, being part of marketing management "means taking steps to define the methods of implementing the set marketing targets of a company through the involvement of its real and potential resources in a particular marketing environment" [Grębosz 2008, p. 100].

Nowadays, the marketing communication campaigns should underline the material characteristics of products, but especially supply information about the brand intangible values. Consequently, in promotional campaigns one should stress brand values associated not only with the product itself but with a lifestyle, security, promoting freedom, joy, fun etc. Highlighting the relations of brand with the past can be a vital element of a communication campaign. It allows for reaching potential customers, opinion-forming sources as well as distributors and allows for emphasizing features essential for each of these groups.

The aim of marketing communication is not only to stress brand advantages but also boost the customer's ego. The nostalgic brand is a source of value added for the customer (reconnection with his past, making the value he believes in more public, thereby telling his story to the members of his group) [Kessous et al. 2015, p. 196].

\section{Examples of retro-style in marketing communication}

The companies use retro-style in marketing communication, both on local and global levels. In case of local marketing campaigns, the reference to the past is often 
connected with underlining the local authenticity, history and tradition. In case of global brands, retro-campaigns are used especially to emphasise the special brand character, its history and timeless values. The objectives of these retro-campaigns are focused on the development of the brand equity and reinforcement of the brand image.

The Coca-Cola Company has celebrated its 125th year in 2011 through a series of activities in over 200 countries where it operates. Coca Cola's celebration included a retrospective TV ad, outdoor ads, online "Retro Poster Maker" and iconic graphics on-pack. Each element of the campaign was influenced by the brand's rich and iconic heritage over the decades, as well as bringing to life its enduring appeal and celebrating 125 years of bringing happiness in a bottle to consumers [Macleod 2011]. The retro style of this campaign helped to underline intangible values related to this global brand, universal all over the world (Figure 1).

\section{Figure 1. Retro-style campaign of Coca-Cola}

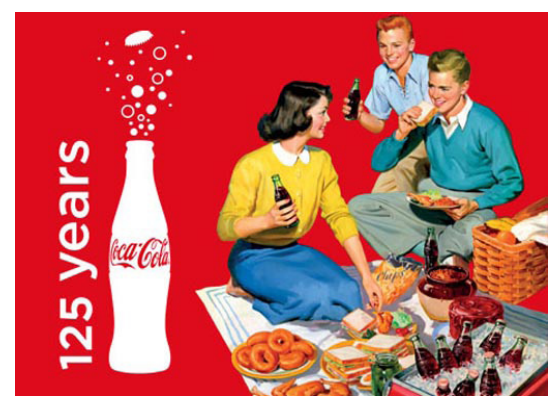

Source: http://theinspirationroom.com/daily/2011/coca-cola-celebrates-125-years [29 Jul 2015].

The owner of Chupa Chups brand has launched in 2012, the retro campaign "Chupa Chups. Now with gum" in order to introduce the new version of product (Figure 2). "The Chupa Chups Now with Gum ad campaign is at once simple and clever. It depicts three models, each of which appeals to a different demographic, playing with their gum in a way that would often warrant a minor chiding from their mothers" [Young 2013]. 


\section{Figure 2. The Chupa Chups retro campaign}
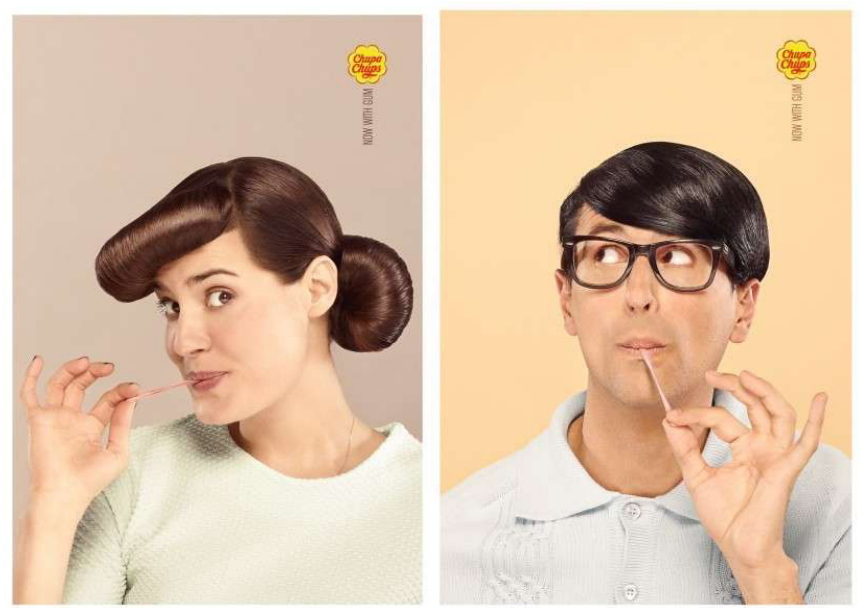

Source: http://adsoftheworld.com/media/print/chupa_chups_now_with_gum_3 [30 Jul 2015].

The Levi's has used retro-style in fall-winter advertising campaign in 2013. The communication campaign paid tribute to two iconic eras of American style: Detroit's '60s Motown musical revolution and the West Coast's sunny '60s style (Figure 3). Levis underlined the timelessly and iconic character of the brand and associated it with the simple and refined models as well as the message of free and open spirit of the time [http://www.gorgeautiful.com/levis-vintage-clothing-fallwinter-2013-ad-campaign].

Figure 3. The Levi's retro campaign

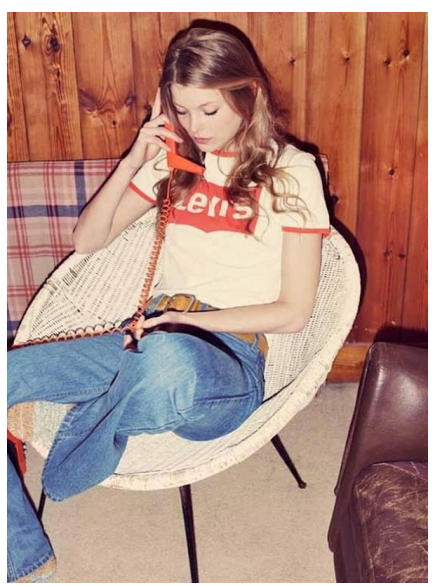

Source: http://www.gorgeautiful.com/levis-vintage-clothing-fall-winter-2013-adcampaign [30 Jul 2015]. 
The retro-style is used also by luxury companies that emphasize the exclusive character of its global brands. In 2011 and 2012, Dior launched advertising campaigns of the brand "Eau Sauvage" with iconographic images of young Alain Delon (Figure 4). Dior recycled images of a mythical movie of the famous actor to remember that the product, and with it the Dior brand, have a history. The retro style used in this campaign makes also the connection with the French culture and in consequence creates the nostalgic feelings.

Figure 4. The retro campaign of Eau Sauvage brand of Dior

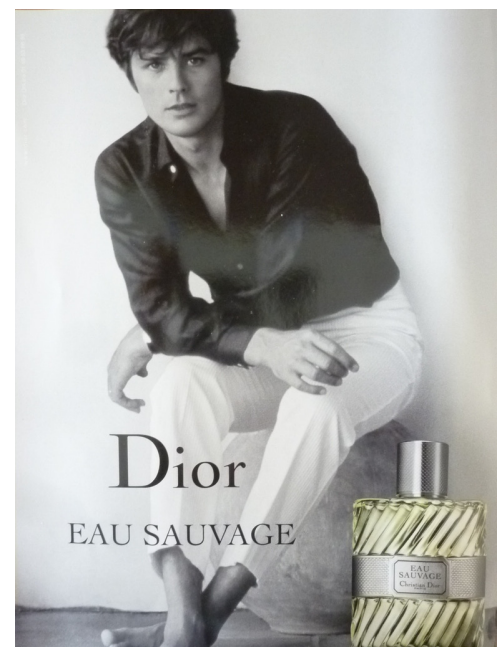

Source: http://www.arretsurimages.net [16 March 2015].

By the retro character, the Lancaster communication campaign in 2013 was clear, intriguing and sophisticated (Figure 5). "The ads were filled with retro details that gives the modern city an old school feel, combining the new with a classic edge" [Chen 2013]. 


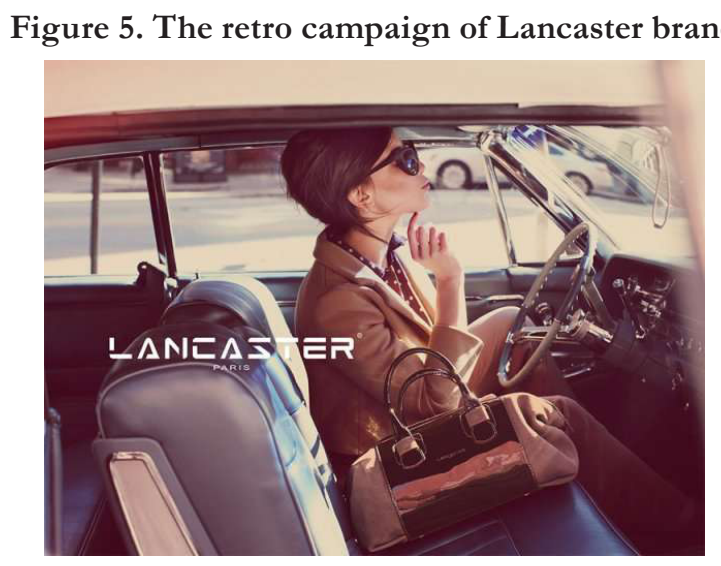

Source: http://www.trendhunter.com/trends/lancaster-fall-2013 [31 Jul 2015].

\section{Results of empirical research}

The main objective of the empirical study was the comparison of French and Polish consumers attitudes towards brands based on "retro" communication, taking into account the product category. Teaching, young people seems interested in retro marketing cases studies, drawing them into stories and making the dream. However, "from 1990's onwards, the baby-boomers, a large and affluent market segment, started to buy products from the past, without shameful nostalgia, and were then followed by young people" [Hallegatte 2015]. Thus, the authors assumed the impact of retro marketing is higher for consumers with a longer and richer life experience.

This research was conducted among 400 young respondents (19-24 years old) in France and in Poland in the first and second quarters of 2015. A method of the non-probability sampling, which is based on the convenience sampling was used. The study was in the form of a research experiment, in that its subject were staged examples of brands commercials in retro-style. During the realization of research, the indirect method of gathering information, using a survey technique was applied. The measurement scales designed to assess attitudes towards brands, created by among others Aaker [1991], Cristau [2001], Lacoeuille [2000], Haberland \& Dacin [1992], Bessemer \& O'Quinn [1986], Pascal, Sprott \& Muehling [2002], Magne [2004] and Chun-Chin Chen [2014], were applied. The Likert scale was used for the advertisings evaluation. The experiment, however, is proprietary in nature. Respondents were not informed of the actual objective of the survey. 
Table 1. Characteristic of the research among consumers

\begin{tabular}{|l|l|l|}
\hline Scope of studies & Characteristics - France & Characteristics - Poland \\
\hline Objective scope & $\begin{array}{l}\text { Identification and comparison of the consumers attitudes towards "retro" } \\
\text { communication of global brands }\end{array}$ \\
\hline Subjective scope & $\begin{array}{l}\text { 200 consumers (19-24 years old), } \\
\text { students of Université Paris Est } \\
\text { (France) }\end{array}$ & $\begin{array}{l}\text { 200 consumers (19-24 years old), } \\
\text { students of Lodz University of } \\
\text { Technology (Poland) }\end{array}$ \\
\hline Spatial scope & Paris region & Lodz Province \\
\hline Time range & The first quarter of 2015 & The second quarter of 2015 \\
\hline
\end{tabular}

Source: own elaboration.

Two well-known global brands from food and textile sector were chosen, that used - among others - the retro-style communication. The advertisings were presented in form of pictures.

To evaluate consumers attitudes towards retro-style communication, the respondents were asked to assess in scale (from - 2 (strongly disagree) to 2 (strongly agree)) the following opinions:

- the advertising is unique,

- the advertising is stylish,

- the message of the advertising is simple and strong,

- the advertising leads me to choose this brand.

In majority, both French and Polish young consumers evaluated the retro-style commercial of global brand from food sector as unique with simple and strong message (Figure 6). Clear message referring to the past makes advertising is judged to be exceptional. In the case of brands of food product, young consumers do not expect detailed product characteristics, reference to innovative technologies, or current trends in nutrition. Both French and Polish young respondents highly valued the simplicity of the message. Retro style as a reassuring reference proves to be an authentic differentiator and is positively rated by consumers. 
Figure 6. Evaluation of the advertising uniqueness and advertising's message global brand from food sector
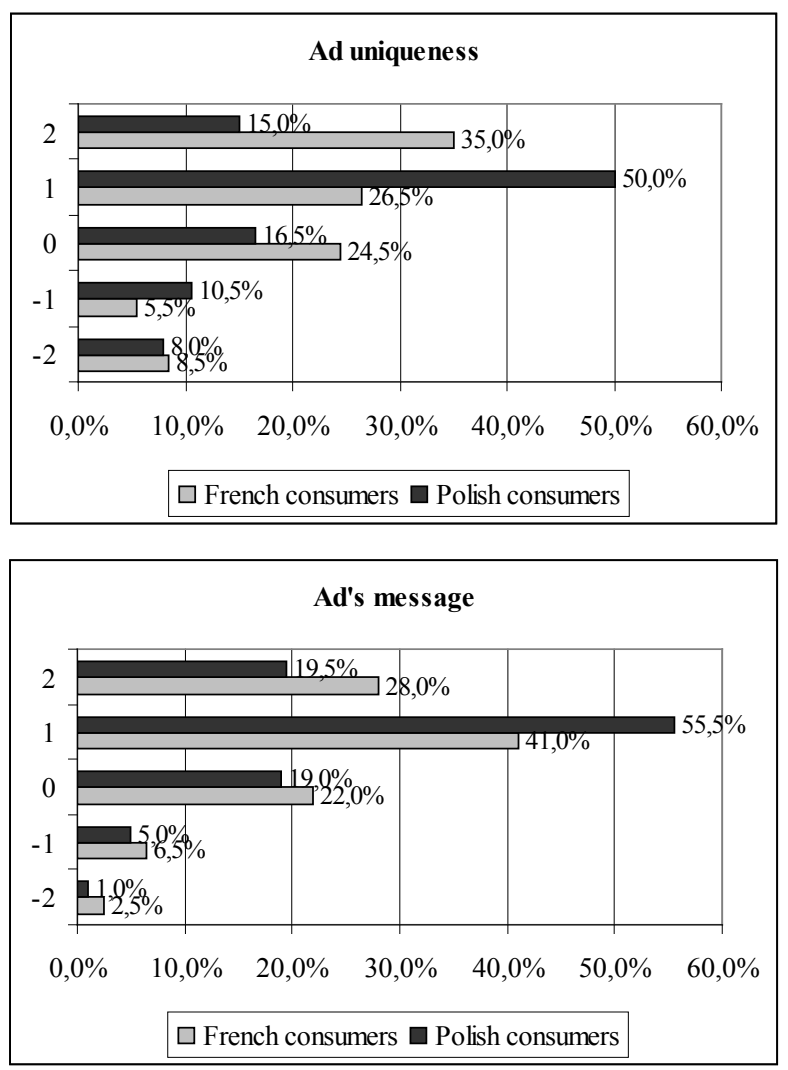

Source: own elaboration based on the research results.

The results were not so evident in case of brand from textile sector (Figure 7). $47 \%$ of French respondents agreed or strongly agreed that the ad is unique and in case of Polish consumers, it was $44 \%$. A third of respondents had no opinion. It can be connected with the product character and the need of seeking the new, fashionable trends. Lack of positive evaluation by more than $50 \%$ of respondents can be also connected with the characteristic of the respondents group. Do the young consumers can expect more modern than traditional campaigns in case of textile brands? The youth behaviour is difficult to understand: they claim to trademark the snapshot and innovation continuously and are simultaneously immersed in the past to highlight vinyls and outfits of their parents. This generation likes to mix the old with the new to create something own. These are not just products they 
buy. They like to assemble different styles including old style, to create something completely new and very modern. Finally, they create the conditions of the brand's nostalgic status developed by Kessous et al. [2015]: “a brand's nostalgic status has a positive effect on attachment, self-brand connections, and storytelling (...) Consumer relationships with nostalgic brands are systematically stronger than with non-nostalgic brands".

Figure 7. Evaluation of the advertising uniqueness and advertising's message global brand from textile sector
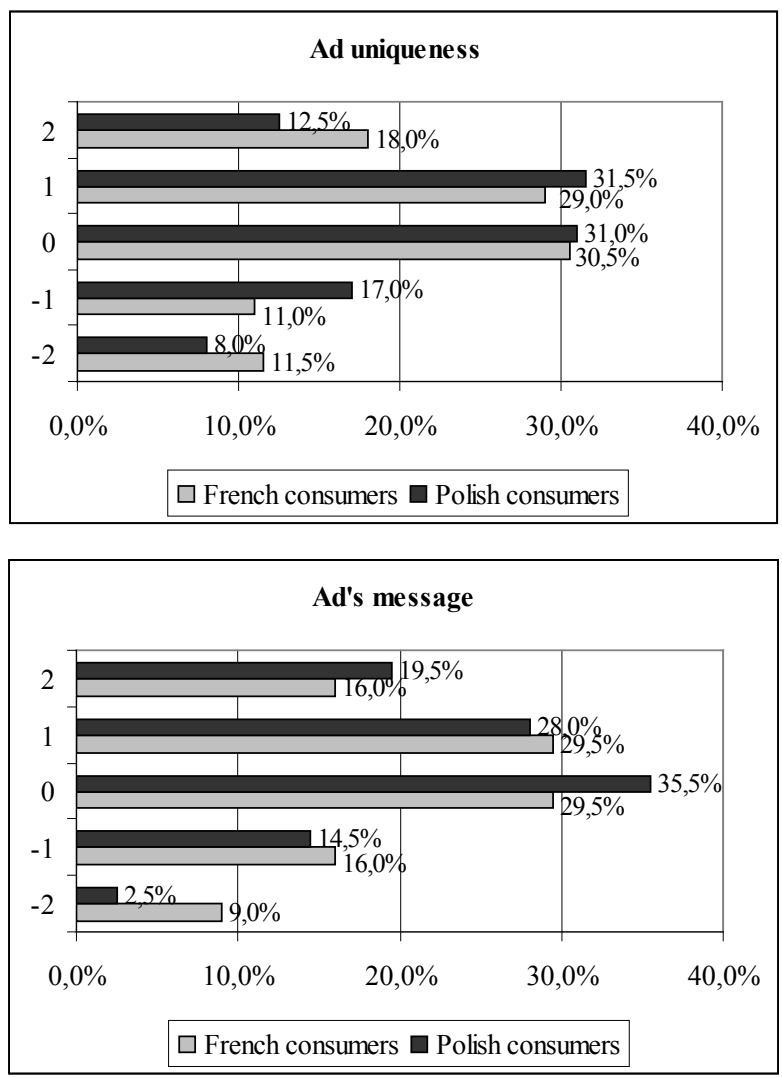

Source: own elaboration based on the research results.

However, for both brands, retro-ads were assessed as stylish equally by French and Polish young consumers (Figure 8). It demonstrates the desire to search for something original, surprising and classy. The retro-ads are not perceived as conventional, boring or old. The young consumers in majority evaluate them as 
stylish, that means they would to be surprised and feel emotional by an aesthetic response to evocations of the past.

Figure 8. Evaluation of the advertising style
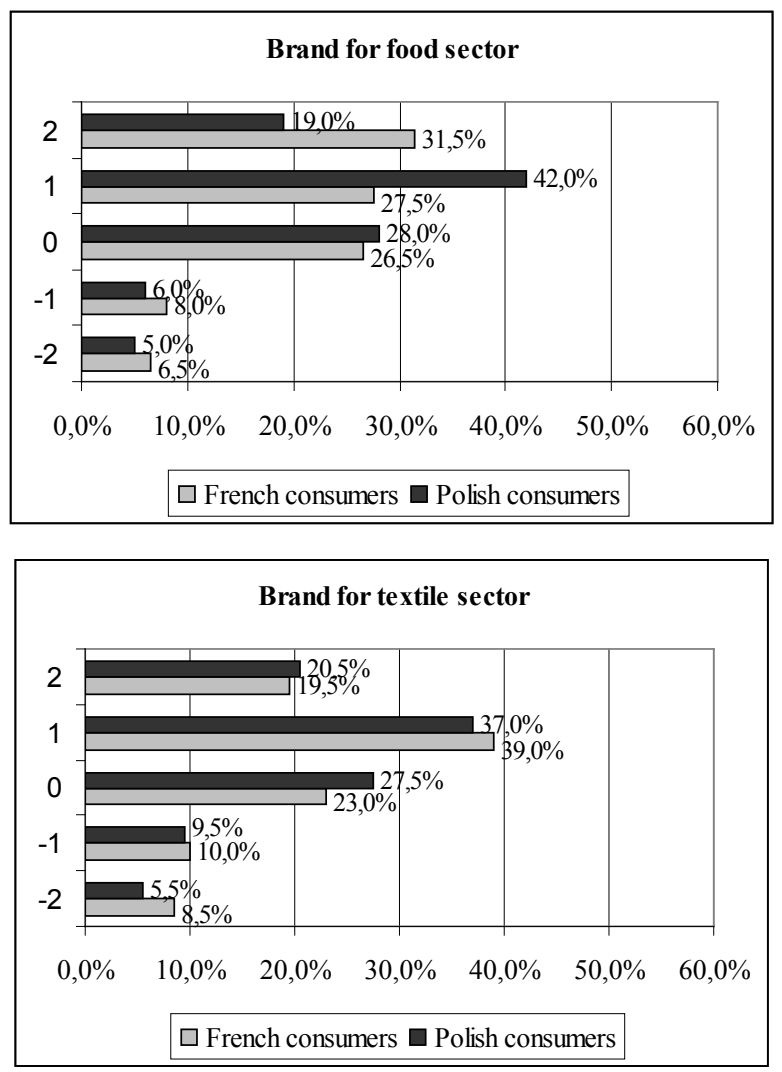

Source: own elaboration based on the research results.

Despite the positive assessment of advertisings style, uniqueness and messages, the retro ads in both cases are not the motivator for the purchase (Figure 9). Only $37 \%$ of French and $29,5 \%$ of Polish young consumers agreed with the statement that retro-advertising leads them to choose the brand from the food sector. The results were almost similar in case of textile brand. It confirms the previous reflections that retro-campaigns are used mainly to develop the brand equity, reinforce the brand image, differentiate or even reposition the brand that to influence directly on the sales volume. 
Figure 9. Evaluation of the purchase intention
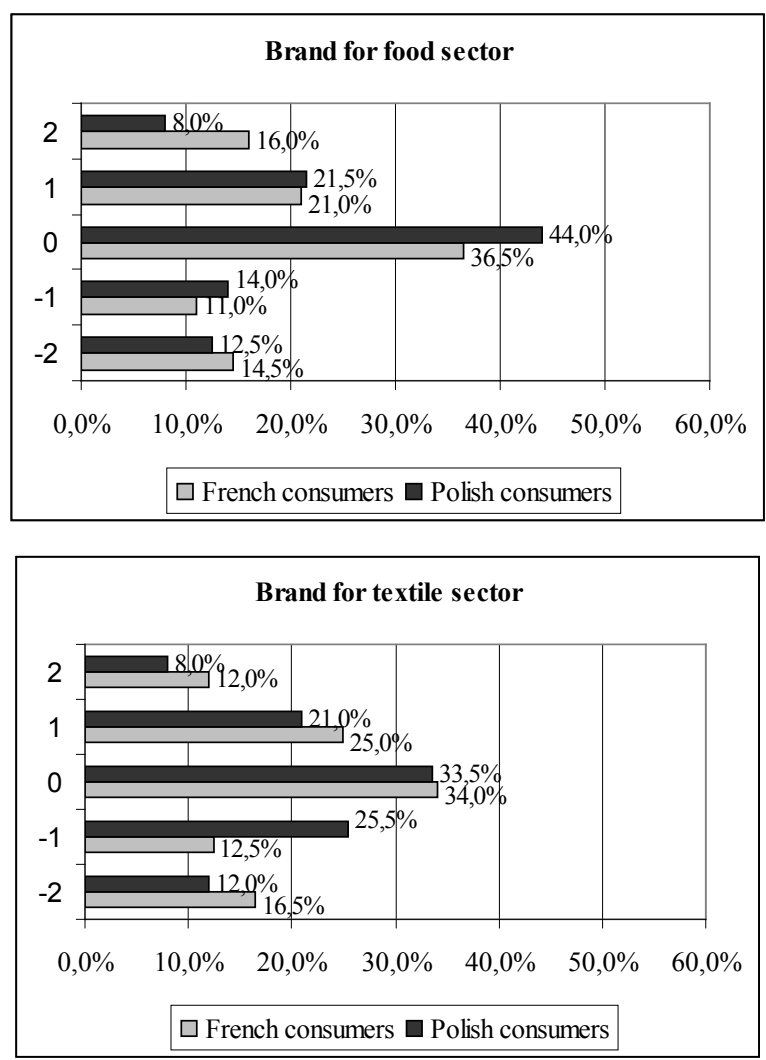

Source: own elaboration based on the research results.

The analysis of research results proved also the consumers attitudes internationalization. The attitudes of French and Polish consumers towards retrocampaigns of global brands are analogous.

\section{Final remarks}

Consequently, as environment instability increases, people tend to look for security and emotional support in the past [Stern 1992, pp. 11-13], and therefore their nostalgic feelings would increase. The fact that a mark is associated in the past consumers head is a strategic advantage [Hallegatte 2015, p. 8]. Like Badot [2014, p. 226], the authors identified some examples of retro communication campaigns of global brands witch become source of hedonistic gratification "indeed, an experience that compensates for the shortcomings of other institutions (government, religion, college etc.) that are perceived to be inadequate". The results 
of the research confirm the significance of retro marketing communication in case of global brands in current market conditions.

The "retro" trend in marketing communication strategy of global brands seems to have interest among young people if they can reclaim it into modern trends. This condition creates positive effect on attachment, self-brand connections, and storytelling.

Taking into account the developing needs of consumers of beauty, pleasure, joy, satisfaction, goodness, happiness, love and security, the implementation of retro-style into the global brand communication can create fantasy universes and atmospheres and bring a refreshing and positive effect. It re-enchants the disenchanted consumer.

\section{References}

Badot O. (2014), Mediterranean marketing and postmodern marketing: An oxymoron?, "Journal of Consumer Behaviour", vol. 13, no. 3, May/June, pp. 224-229.

Baker S.M., Kennedy P.F. (1994), Death by Nostalgia: A Diagnosis of Context-Specific Cases, "Advances in Consumer Research", vol. 21, pp. 169-74.

Belk R.W. (1990), The Role of Possessions in Constructing and Maintaining a Sense of Past, "Advances in Consumer Research", vol. 17, pp. 669-676.

Brown S. (2001), The retromarketing revolution: limagination au pouvoir, "International Journal of Management Reviews", vol. 3, no. 4, December, pp. 303-320.

Davis F. (1979), Yearning for Yesterday: A Sociology of Nostalgia, New York: Free Press.

Divard R., Robert-Demontrond Ph. (1997), La Nostalgie: Un Thème Récent dans la Recherche Marketing, 'Recherche et Applications en Marketing', vol. 12, no. 4, pp. 41-62.

Firat A.F., Venkatesh A. (1995), Liberatory Postmodernism and the Reenchantment of Consumption, 'Journal of Consumer Research', vol. 22, no. 3, pp. 239-267.

Hallegatte D. (2015), Retromarketing: how marketing has turned to the past, International Marketing Trends Conference, January $23^{\text {td }}$ and $24^{\text {th }}$, Paris.

Holbrook M.B, Schindler R.M. (1991), Echoes of the Dear Departed Past: Some Work in Progress on Nostalgia, "Advances in Consumer Research", vol. 18, pp. 330-33.

Kessous A., Roux E., Chandon J-L. (2015), Consumer-Brand Relationships: a contrast of nostalgic and non-nostalgiec brands, "Psychology \& Marketing", vol. 32 (2), pp. 187-202.

Marchegiani Ch.A., Phau I. (2010), Effect of Personal Nostalgic Response Intensity on Cognitions, Attitudes, and Intentions, "Journal of Research in Interactive Marketing", vol. 4, no. 3, pp. 241-56.

Maffesoli M. (2003), Linstant éternel, le retour du tragique dans les société postmodernes, Paris: La Table Ronde.

Muehling D.D. (2013), The Relative Influence of Advertising-Evoked Personal and Historical Nostalgic Thoughts on Consumers' Brand Attitudes, "Journal of Marketing Communications", vol.19, no.2, pp. $98-113$. 
Muehling D.D., Pascal V.J. (2011), An Empirical Investigation of the Differential Effects of Personal, Historical, and Non-Nostalgic Advertising on Consumer Responses, "Journal of Advertising", vol. 40, no. 2, pp. 107-122.

Muehling D.D., Sprott D.E. (2004), The Power of Reflection: An Empirical Examination of Nostalgia Advertising Effects, "Journal of Advertising”, vol. 33, no. 3, pp. 25-35.

Muehling D.D., Sprott D.E., Sultan A. (2014), Exploring the Boundaries of Nostalgic Advertising Effects: A Consideration of Childhood Brand Exposure and Attachment on Consumers' Responses to Nostalgia-Themed Advertisements, "Journal of Advertising", vol. 43, no.1, pp.73-84.

Pascal V.J., Sprott D.E., Muehling D.D. (2002), The Influence of Evoked Nostalgia on Consumers' Responses to Advertising: and Exploratory Study, "Journal of Current Issues and Research in Advertising", vol. 24, no.1, pp. 39-49.

Perrusson C. (2003), Contribution à une meilleure compréhension des effets de la nostalgie évoquée dans l'annonce publicitaire: une application aux messages télévisés, doctoral dissertation, Paris: University Paris I Panthéon Sorbonne.

Reisenwitz T.H., Iyer R., Cutler B. (2004), Nostalgia Advertising and the Influence of Nostalgia Proneness, "Marketing Management Journal", vol.14, no. 2, pp. 55-66.

Stern B.B. (1992), Historical and Personal Nostalgia in Advertising Text: The Fin de Siecle Effect, "Journal of Advertising", vol. 21, no. 4, pp. 11-22.

Zhou L. Wang T., Zhang Q., Mou Y. (2013), Consumer insecurity and preference for nostalgic products: Evidence from China, "Journal of Business Research", vol. 66, pp. 2406-2411.

\section{Electronic references}

Chen L. (2013), Daisy Lowe Stars in these Sophisticated Lancaster Fall 2013 Ads, [Online], Available: http://www.trendhunter.com/trends/lancaster-fall-2013 [30 Jul 2015].

Macleod D. (2011), Coca Cola Celebrates 125 Years, [Online], Available: http://theinspirationroom.com/daily/2011/coca-cola-celebrates-125-years/ [29 Jul 2015].

Young M. (2013), The Chupa Chups Now with Gum Campaign is Simple and Retro, [Online], Available: http://www.trendhunter.com/trends/chupa-chups-now-with-gum [30 Jul 2015].

http://adsoftheworld.com/media/print/chupa_chups_now_with_gum_3 [30 Jul 2015].

http://www.gorgeautiful.com/levis-vintage-clothing-fall-winter-2013-ad-campaign $\quad$ [30 Jul 2015].

http://www.arretsurimages.net/ [16 March 2015]. 